\title{
Nonsuppressible Insulin-Like Activity of Human Serum
}

\author{
A POTENT INHIBITOR OF INSULIN DEGRADATION
}

\author{
C. Ronald Kahn, Klara Megyesi, and Jesse Roth \\ From the Diabetes Branch, National Institute of Arthritis, Metabolism, and \\ Digestive Diseases, National Institutes of Health, Bethesda, Maryland 20014
}

A в S T R A C T Nonsuppressible insulin-like activity soluble in acid ethanol (NSILA-s) is a well-characterized peptide derived from human serum which has previously been shown to have insulin-like bioactivity and react with both insulin and NSILA-s receptor sites in liver plasma membranes. In the present study we find that NSILA-s is also a potent competitive inhibitor of the insulin-degrading system of the liver plasma membrane. The most purified NSILA-s preparation tested was 20 -fold more potent than insulin itself, and significant inhibition of insulin degradation occurred at concentrations of NSILA-s similar to those found in plasma.

\section{INTRODUCTION}

Serum contains multiple components that have insulinlike biological activity. Aside from insulin and proinsulin, one of the best characterized of these components is the nonsuppressible insulin-like activity soluble in acid ethanol (NSILA-s) ${ }^{1}(1,2)$. Although the exact structure of NSILA-s is unknown, it appears to be considerably different from that of insulin (2). Despite these differences, the spectrum of biological activities of insulin and NSILA-s are remarkably similar, although insulin is more potent in stimulating acute metabolic effects (2), while NSILA-s is more potent in stimulating growth-promoting effects (3). In previous studies using liver plasma membranes, we demonstrated that these different effects probably arose through the interaction of these two peptides with two separate membrane receptors, one which has a higher affinity for NSILA-s and one which has a higher affinity for insulin (4-6).

Dr. Megyesi is a Guest Worker on leave from the Semmelweis Medical University, Budapest, Hungary.

Received for publication 16 August 1975 and in revised form 23 October 1975.

${ }^{1}$ Abbreviation used in this paper: NSILA-s, nonsuppressible insulin-like activity soluble in acid-ethanol.
Liver plasma membranes possess an insulin-degrading enzyme(s) which shows a high degree of specificity for insulin as opposed to other polypeptide hormones but is independent of the insulin receptor as judged by its affinity for insulin, specificity for insulin analogues, and $\mathrm{pH}$ and temperature optima (7). In the present study we find that NSILA-s is a potent competitive inhibitor of this insulin-degrading system; this suggests yet one more insulin-like property of this molecule.

\section{METHODS}

NSILA-s, generously provided by Doctors E. R. Froesch and R. E. Humbel, had been extracted from pooled human plasma into acid-ethanol and partially purified by gel filtration $(2,8)$. Six preparations, which varied in insulin-like potency measured by stimulation of glucose oxidation in rat adipose tissue from 1 to $70 \mathrm{mU} / \mathrm{mg}$, were used. The most purified preparation used in these experiments $(70 \mathrm{mU} / \mathrm{mg}$ ) is about $15-20 \%$ as potent on a weight basis as the most highly purified NSILA-s (2). All of the NSILA-s preparations inhibited ${ }^{125} \mathrm{I}$-insulin binding to liver membranes and cultured lymphocytes in rank order of their potency in the fat pad glucose oxidation assay (Table I) (6). Radioimmunoassay revealed that on a weight basis less than $0.0001 \%$ of the most purified preparation $(70 \mathrm{mU} / \mathrm{mg}$ ) could be accounted for by immunoreactive insulin or proinsulin; this count account for, at most, $0.03 \%$ of the biological activity (6). The least purified preparation contained less than $0.1 \%$ immunoreactive insulin or proinsulin (6); while this could account for much of the bioactivity of this preparation, this would not account for its effect on insulin degradation (see below).

Porcine insulin $(25 \mathrm{U} / \mathrm{mg})$ was purchased from Eli Lilly and Co. (Indianapolis, Ind.) and ${ }^{125} \mathrm{I}$-insulin $(100-200 \mu \mathrm{Ci} /$ $\mu \mathrm{g}$ ) was prepared using a modification of the chloramine-T oxidation method (7). Highly purified rat liver plasma membranes, a generous gift of Dr. D. M. Neville, Jr., was prepared as previously described (9).

Degradation experiments were conducted in duplicate in 400- $\mu 1$ microfuge tubes in a Krebs-Ringer phosphate buffer, $\mathrm{pH} 7.5$, with $1 \%$ bovine serum albumin. The total incubation volume was $150 \mu \mathrm{l}$. In most of these experiments, ${ }^{125} \mathrm{I}$-insulin $(100 \mathrm{pg} / \mathrm{ml})$ was incubated with liver membranes $(0.2-0.4 \mathrm{mg} / \mathrm{membrane}$ protein per $\mathrm{ml})$ for $2-3 \mathrm{~h}$ at $30^{\circ} \mathrm{C}$ in the presence of unlabeled insulin or NSILA-s as indi- 
TABLE I

Potencies of Insulin and NSILA-s in Inhibiting Three Membrane Recognition Sites

\begin{tabular}{|c|c|c|c|c|c|c|}
\hline & \multicolumn{2}{|c|}{ 125I-insulin binding* } & \multicolumn{2}{|c|}{ 126I-insulin degradationf } & \multicolumn{2}{|c|}{ 125I-NSILA-s binding* } \\
\hline & EDso\& & $\begin{array}{l}\text { Relative } \\
\text { potency }\end{array}$ & EDso & $\begin{array}{l}\text { Relative } \\
\text { potency }\end{array}$ & EDso & $\begin{array}{l}\text { Relative } \\
\text { potency }\end{array}$ \\
\hline Insulin & $0.03 \mu \mathrm{g} / \mathrm{ml}$ & 1.000 & $3.6 \mu \mathrm{g} / \mathrm{ml}$ & 1.000 & $>1,000 \mu \mathrm{g} / \mathrm{ml}$ & 1.000 \\
\hline \multicolumn{7}{|c|}{ NSILA-s preparation, $m U / m g$} \\
\hline 70 & 1.2 & 0.025 & 0.17 & 21.2 & 0.003 & $333,000.0$ \\
\hline 31 & 2.4 & 0.012 & 1.3 & 2.77 & 0.008 & $125,000.0$ \\
\hline 21 & 11 & 0.0027 & 2.2 & 1.62 & 0.12 & $8,300.0$ \\
\hline 8 & 33 & 0.0009 & 30 & 0.12 & 0.30 & $3,300.0$ \\
\hline 2.7 & 33 & 0.0009 & 30 & 0.12 & 0.20 & $5,500.0$ \\
\hline 1 & 500 & 0.00006 & 136 & 0.025 & 0.40 & $2,500.0$ \\
\hline REA-31\| & $>>1,000$ & $<0.00003$ & 100 & 0.036 & $>100$ & $\sim 10.0$ \\
\hline
\end{tabular}

* Adapted from Megyesi et al. (6). The data presented are from experiments employing cultured human lymphocytes, but virtually identical data were obtained when ${ }^{125} \mathrm{I}$-insulin binding to liver membranes was studied.

$\ddagger$ From Fig. 1 .

\$ Concentration required to produce a $50 \%$ inhibition of the effect.

|| REA-31 is a reduced and aminoethylated preparation prepared from the $31-\mathrm{mU} / \mathrm{mg}$ preparation.

cated in the legend to the figures. At the end of the incubation, the membrane was sedimented in a Beckman microfuge (Beckman Instruments, Inc., Spinco Div., Palo Alto, Calif.) for $1 \mathrm{~min}$ and the supernatant removed. Intact ${ }^{105} \mathrm{I}-$ insulin in the supernate was determined by precipitation with $5 \%$ TCA (7). The values of apparent $K_{m}$ obtained by this method are in good agreement with the more sensitive methods and can be obtained over a wider range of hormone concentrations (7). In each experiment, controls were prepared which were identical with respect to ${ }^{128} \mathrm{I}$ insulin, insulin, and NSILA-s concentrations except that membranes were omitted. The percent of ${ }^{125} \mathrm{I}$-insulin degraded was then calculated as follows:

$$
\% \text { Degraded }=\left[\frac{\% \text { intact in experimental tube }}{\% \text { intact in control tube }}\right] \times 100
$$

In all experiments, there was less than $3 \%$ degradation of hormone in the control tube.

\section{RESULTS}

After $3 \mathrm{~h}$ of incubation with liver plasma membranes $(0.3 \mathrm{mg} / \mathrm{ml})$ at $30^{\circ} \mathrm{C}$ about $40 \%$ of the ${ }^{180} \mathrm{I}$-insulin present in the incubation tube $(100 \mathrm{pg} / \mathrm{ml})$ was degraded to TCA-soluble material. Unlabeled insulin significantly inhibited degradation of the ${ }^{120} \mathrm{I}$-insulin (Fig. 1) in concentrations as low as $500 \mathrm{ng} / \mathrm{ml}$ and, under these conditions, produced a $50 \%$ reduction in degradation at a concentration of about $3.6 \mu \mathrm{g} / \mathrm{ml}(0.6 \mu \mathrm{M})$. We have previously demonstrated ( 7 ) that this inhibition of degradation is quite specific for intact insulin and its analogues; growth hormone, glucagon, oxytocin, and isolated A and B chains of insulin have no effect on inhibiting degradation.

NSILA-s is a potent inhibitor of the insulin degradation and, in general, this inhibitory activity is proportional to the insulin-like potency of the preparation
(Fig. 1 and Table I). The most purified preparation tested $(70 \mathrm{mU} / \mathrm{mg})$ produced a $50 \%$ inhibition of degradation at a concentration of $170 \mathrm{ng} / \mathrm{ml}$. The 31 - and $21-\mathrm{mU} / \mathrm{mg}$ preparations were also more active in in-

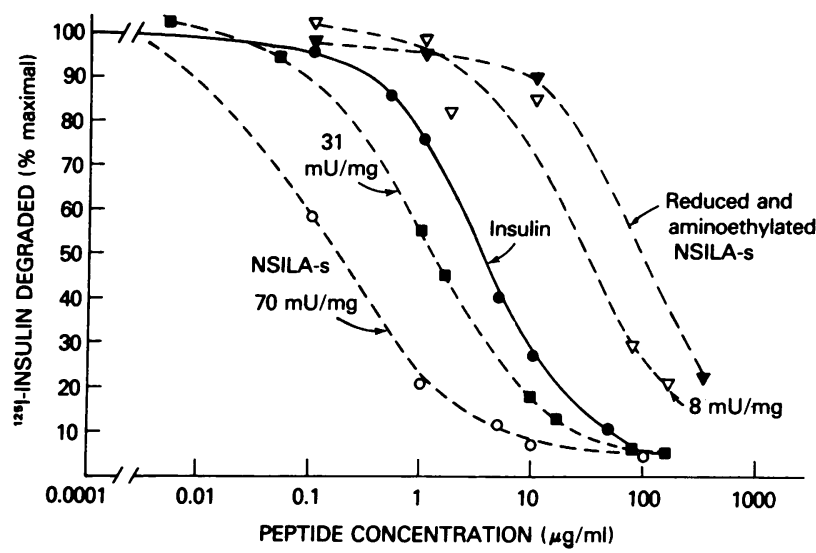

FIGURE 1 Effect of NSILA-s on ${ }^{125}$ I-insulin degradation by liver plasma membranes. ${ }^{125} \mathrm{I}$-insulin $(100 \mathrm{pg} / \mathrm{ml})$ was incubated with purified liver plasma membranes $(0.3 \mathrm{mg}$ protein $/ \mathrm{ml}$ ) in $150 \mu \mathrm{l}$ of Krebs-Ringer phosphate, $\mathrm{pH} 7.4$, containing $1 \%$ bovine serum albumin and concentrations of unlabeled insulin and NSILA-s as indicated. After $3 \mathrm{~h}$ at $30^{\circ} \mathrm{C}$ the membrane was sedimented and the percent of ${ }^{125} \mathrm{I}$-insulin intact in the supernate was determined by TCA precipitation as described in Methods. About $40 \%$ of the ${ }^{225} \mathrm{I}$-insulin $(10,000-15,000 \mathrm{cpm} /$ incubation tube) was degraded in the absence of unlabeled NSILA-s or insulin. The data for each NSILA-s preparation represent the mean of two or three separate experiments each done in duplicate. For clarity, the data on the 21-, 2.7-, and 1-mU/ $\mathrm{mg}$ preparations have been omitted from the figure but are given in Table I. 
hibiting degradation than was insulin, despite the fact that the preparations are only $1 / 1,000$ th as potent as insulin in bioactivity. A $31-\mathrm{mU} / \mathrm{mg}$ preparation which had been reduced and aminoethylated (2) was about $1 \%$ as active as the native preparation in inhibiting degradation, but this residual inhibitory activity still exceeded the residual insulin-like bioactivity and receptor activity by over 10 -fold.

To determine the nature of this inhibition, the effect of NSILA-s on insulin degradation was studied over a wide range of insulin and NSILA-s concentrations. When the velocity of degradation was determined in the presence and absence of two different preparations of NSILA-s and the results were plotted by the method

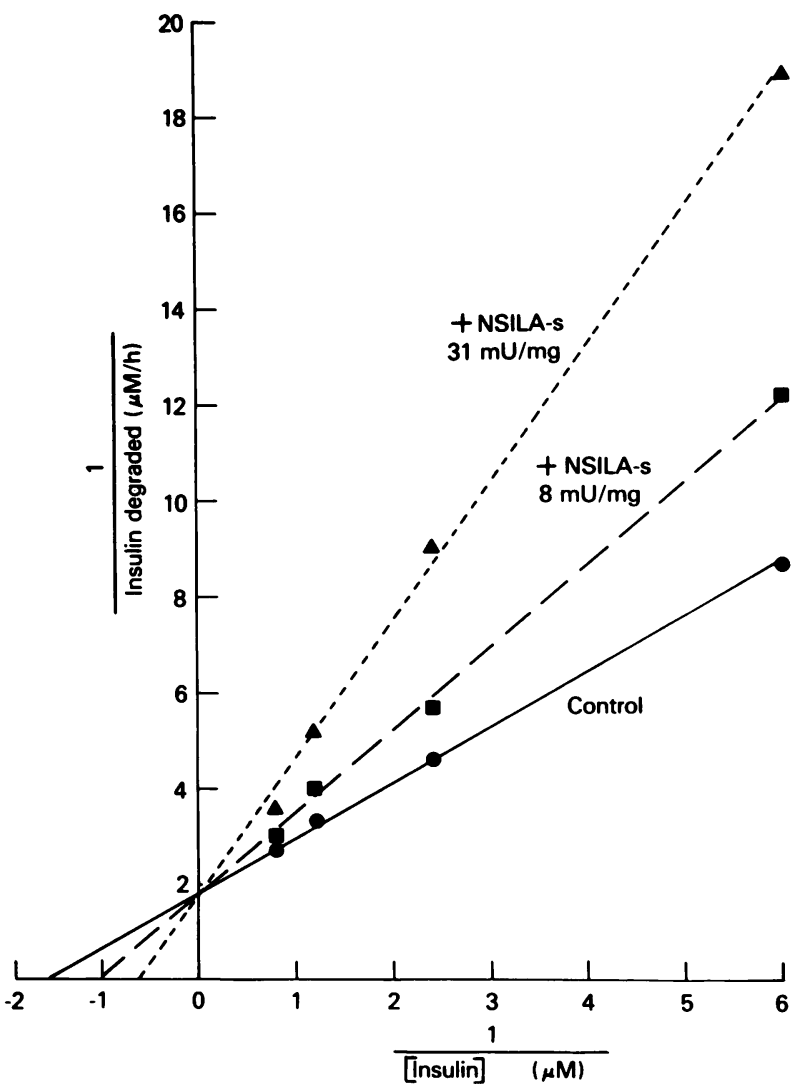

Figure 2 Lineweaver-Burk plot of insulin degradation and inhibition by NSILA-s. Three sets of tubes containing ${ }^{120} \mathrm{I}-$ insulin $(100 \mathrm{pg} / \mathrm{ml})$ and unlabeled insulin $(0.17-1.7 \mu \mathrm{M})$ were incubated with liver plasma membranes $(0.2 \mathrm{mg}$ protein $/ \mathrm{ml}$ ) as described in Fig. 1 at $30^{\circ} \mathrm{C}$ for $1 \mathrm{~h}$. In addition, one set contained $3.3 \mu \mathrm{g} / \mathrm{ml}$ of the $31-\mathrm{mU} / \mathrm{mg}$ NSILA-s and the other contained $6.6 \mu \mathrm{g} / \mathrm{ml}$ of the $8-\mathrm{mU} / \mathrm{mg}$ NSILA-s. The amount of insulin degraded was calculated at each insulin concentration by multiplying the percent of ${ }^{125}$ I-insulin degraded times the total insulin concentration. The data were then plotted by the method of LineweaverBurk (10) of Lineweaver and Burk (Fig. 2) (10), three straight lines were obtained which intersected at the ordinate, indicating that NSILA-s behaves as a competitive inhibitor of the insulin-degrading system in the liver membranes. In these experiments, the calculated $K_{m}$ for insulin degradation was $0.6 \mu \mathrm{M}$, a value similar to that previously reported for liver membranes (7). The $K_{\text {}}$ calculated for "pure" NSILA-s, if one assumes a $10 \%$ purity for the $31-\mathrm{mU} / \mathrm{mg}$ preparation (since the most purified preparation has an insulin-like activity of about $350 \mathrm{mU} / \mathrm{mg}$ ) and a molecular weight of 7,400 , is $30 \mathrm{nM}$.

\section{DISCUSSION}

Insulin and NSILA-s, while markedly distinguished by immunoreactivity and chemical structure, have many functional properties which are quite similar. Both peptides have insulin-like biological activity and occupy the insulin receptor in liver, fat, and cultured human lymphocytes in direct proportion to their bioactivity $(4,6)$. In addition, both insulin and NSILA-s interact with the "cooperative-site" of these insulin receptors, and induce negative cooperative intersections among insulin receptors. ${ }^{2}$ Liver plasma membranes also possess NSILA-s receptors which are separate from the insulin receptors, and again both peptides can occupy this receptor which presumably initiates their growthpromoting effects $(4,6)$.

The present study demonstrates yet another similarity between NSILA-s and insulin; recognition by the insulin-degrading enzyme(s) in liver. NSILA-s is a very potent inhibitor of ${ }^{120} \mathrm{I}$-insulin degradation with the most purified preparation tested being about 20 times as potent as insulin on a weight basis, or 16 times as potent on a molar basis in this function. Since this preparation itself is at most $20 \%$ pure $(2,8)$, "pure" NSILA-s, if available, would be about 100 times as potent as insulin in this action. It is possible that the inhibitor is a contaminant of the NSILA-s preparations, but this seems unlikely since the inhibitory activity co-purifies with the insulin-like bioactivity. Furthermore, the fact that the inhibition is competitive in nature argues strongly that the inhibitory activity is not the nonspecific effect of a peptide. This effect is similar to that observed by proinsulin which is also a competitive inhibitor of insulin degradation (7), but NSILA-s appears to be almost 10 -fold more potent than proinsulin in this action. Like proinsulin, NSILA-s itself appears to be very slowly degraded by the insulin-degrading system of the liver cell membrane (6). If one considers the recognition of insulin and NSILA-s by the three types of membrane recognition sites thus far studied, insulin has the highest affinity for the

${ }^{2}$ De Meyts, P. Personal communication. 
insulin receptor with a lower affinity for the insulindegrading enzyme and an even lower affinity for the NSILA-s receptor; with NSILA-s the order of apparent affinity is reversed (Table I).

Three points regarding the possible significance of this finding deserve comment. Firstly, NSILA-s in plasma circulates at relatively high concentrations (equivalent to $1.5 \mu \mathrm{g} / \mathrm{ml}$ of our $70 \mathrm{mU} / \mathrm{mg}$ standard); of this about $90-95 \%$ is bound to larger molecules and about $5-10 \%$ is free (5). At these concentrations, NSILA-s (or free NSILA-s) reduced insulin degradation by $50-80 \%$ in vitro and may significantly inhibit insulin degradation in vivo. This may play a role in maintainance of normal insulin levels, making more intact insulin available for binding to the receptors. This may also effect insulin half-life in states in which NSILA-s levels are altered. Unfortunately, at the present time, NSILA-p has not been obtained in a sufficiently pure state to test for its effect on insulin degradation; thus, whether it has an additive effect with NSILA-s remains unknown. Secondly, while there is some debate about the nature of the insulin-degrading enzymes in liver $(7,11)$, it is clear that NSILA-s is yet another insulin "analogue" which has a different affinity for the insulin-degrading enzyme and the insulin receptor, again suggesting a difference in these closely linked functions (7). Finally, an additional point should be made regarding the measurement of plasma proinsulin utilizing the "insulin-specific protease" (12), a soluble enzyme from muscle which is very similar to the membrane-bound enzyme in liver we have studied. This enzyme has also been shown to be inhibited by the plasma fractions which contain NSILA-s (13), and since the concentration of NSILA-s in plasma is relatively high, additional caution must be taken in measuring plasma proinsulin by this method.

\section{ACKNOWLEDGMENTS}

The authors wish to acknowledge Ms. Kathleen Baird for her excellent technical assistance.

\section{REFERENCES}

1. Jakob, A., C. Hauri, and E. R. Froesch. 1968. Nonsuppressible insulin-like activity in human serum. III.
Differentiation of two distinct molecules with nonsuppressible ILA. J. Clin. Invest. 47: 2678-2688.

2. Oelz, O., E. R. Froesch, H. F. Bünzli, R. E. Humbel, and W. J. Ritschard. 1972. Antibody-suppressible and nonsuppressible insulin-like activities. Handb. Physiol. 1 (Sect. 7) : 685-702.

3. Rechler, M. M., J. M. Podskalny, I. D. Goldfine, and C. A. Wells. 1974. DNA synthesis in human fibroblasts: Stimulation by insulin and by nonsuppressible insulin-like activity (NSILA-s). J. Clin. Endocrinol. Metab. 39 : 512-521.

4. Megyesi, K., C. R. Kahn, J. Roth, E. R. Froesch, R. E. Humbel, J. Zapf, and D. M. Neville, Jr. 1974. Insulin and non-suppressible insulin-like activity (NSILA-s): Evidence for separate plasma membrane receptor sites. Biochem. Biophys. Res. Commun. 57: 307-315.

5. Megyesi, K., C. R. Kahn, J. Roth, and P. Gorden. 1975. Circulating NSILA-s in man: Preliminary studies of stimuli in vivo and of binding to plasma components. $J$. Clin. Endocrinol. Metab. 41: 475-484.

6. Megyesi, K., C. R. Kahn, J. Roth, D. M. Neville, Jr., P. S. Nissley, R. E. Humbel, and E. R. Froesch. 1975. The NSILA-s receptor in liver plasma membranes: Characterization and comparison with the insulin receptor. J. Biol. Chem. 250: 8990-8996.

7. Freychet, P., C. R. Kahn, J. Roth, and D. M. Neville, Jr. 1972. Insulin interactions with liver membranes. Independence of binding of the hormone and its degradation. J. Biol. Chem. 247 : 3953-3961.

8. Humbel, R. E., H. Bünzli, K. Mülly, O. Oelz, E. R. Froesch, and W. J. Ritschard. 1971. Insulin-like substances: The insulin dimer, and non-suppressible insulinlike activity. Proceedings of the 7th Congress of the International Diabetes Federation, Buenos Aires, 23 August 1970. Excerpta Med. Int. Congr. Ser. 231: 306317.

9. Neville, D. M., $\mathrm{J}_{\mathrm{i}}$. 1968. Isolation of an organ specific protein antigen from cell-surface membrane of rat liver. Biochim. Biophys. Acta. 154: 540-552.

10. Lineweaver, H., and D. Burk. 1934. The determination of enzyme dissociation constants. J. Am. Chem. Soc. 5E : $658-666$

11. Varandani, P. T. 1973. Insulin degradation. X. Identification of insulin degrading activity of rat liver plasma membrane as glutathione-insulin transhydrogenase. Biochem. Biophys. Res. Commun. 55 : 689-696.

12. Kitabchi, A. E., W. C. Duckworth, J. S. Brush, and M. Heinemann. 1971. Direct measurement of proinsulin in human plasma by the use of an insulin-degrading enzyme. J. Clin. Invest. 50: 1792-1799.

13. Burghen, G. A., J. S. Brush, S. S. Salomon, J. N. Etteldorf, and A. E. Kitabchi. 1971. Inhibition of insulin degradation by extracts of human plasma. Diabetes. 20: 342. (Abstr.) 